\subsection{4/hsuf.2018.10.07}

Александр Круглов

\section{ЖЕРТВЫ И ПРЕСТУПНИКИ ОБ УНИЧТОЖЕНИИ ЕВРЕЕВ ОДЕССЫ}

В предыдущем выпуске (№ 9, 2017) научного журнала Проблеми історії Голокосту: український вимір было опубликовано исследование Александра Круглова «Депортация и уничтожение евреев Одессы в северных районах области в 1942 г.»' В статье на основе советских, румынских и немецких документов, многие из которых были впервые введены в научный оборот, рассматривалась судьба около 35 тыс. одесских евреев, которые в первой половине 1942 г. были депортированы в товарных поездах румынскими оккупационными властями в район станции Березовка (Одесская область), откуда они были затем направлены в разные села тогдашних Мостовского, Березовского, Веселиновского и отчасти Вознесенского районов (эти районы образовывали так называемый «уезд Березовка») и главным образом в январе-июне 1942 г. уничтожены здесь отрядами самообороны (Selbstschutz-Abteilung), созданными так называемой зондеркомандой $\mathrm{CC}$ «Р» из числа местных немцев (фольксдойче).

Эти события нашли отражение в многочисленных документах, как опубликованных, так и неопубликованных; из числа последних ниже публикуются четыре документа, которые, на наш взгляд, наиболее показательно и точно иллюстрируют вышеупомянутую тему. Первый документ - это показания одессита Владимира Бирмана, содержащие описание условий, в которых происходила депортация евреев в «уезд Березовка», а также условия их содержания в тех селах, в которые их пригоняли². Два других документа - это показания бывших членов отряда «самообороны», созданном СС (участковая команда XI/Bereichskommando XI) на хуторе Новая Америка (Веселиновский район) Рафаила и Петера Гекк (Хекк), которые принимали активное участие в расстрелах одесских евреев, содержавшихся в разных селах «уезда Березовка». Четвертый документ - это показания бывшего полицейского села Новопетровка (Веселиновский район)

\footnotetext{
${ }^{1}$ Александр Круглов, «Депортация и уничтожение евреев Одессы в северных районах области в 1942 г.», Проблеми історії Голокосту: український вимір, № 9 (2017): 68-99.

${ }^{2}$ См.: Иосиф Каплер, Пути смерти (записки узника гетто) (Москва, 2005), http://www.nasledie-rus. ru/red_port/00106.php\#\#.
}

Яковенко. Этот документ показывает, что активное содействие убийствам евреев оказывали и местные украинские полицейские.

Эти документы соединяют в себе как познавательный, так и чувственно-эмоциональный аспекты. С одной стороны, содержащиеся в публикуемых документах детали и подробности дают возможность получить определенную информацию о трагедии евреев, а с другой позволяют прочувствовать эту трагедию, проникнуться ею, эмоционально ее воспринять. В публикуемых документах сохранены орфография и пунктуация оригинала.

\section{Документ 1. Из показаний 31.3.1944 г. в качестве свидетеля \\ Владимира Бирмана}

11 февраля 1942 г. я был пригнан в предпоследнем этапе со всеми евреями с Одессы в Мостовое на расстрел. По дороге нас сопровождали румынские жандармы, которые на каждом километре делали привал, чтобы нас ограбить. За ними, т.е. румынскими жандармами, ехали повозки местного населения, которые покупали отобранные вещи. Видны были такие картинки: мужчины в подштанниках, без пальто и костюма, женщины без туфель, дети босиком без ботиночек и галош. Это все по дороге отбирали румынские жандармы и помогали им мальчишки, сопровождая нас криками: «Уже кончилась ваша большевистская власть». На каждом шагу лежали трупы стариков, старух и детей. Шли с нами много русских женщин, мужья которых были евреями и по закону эти дети смешанных браков тоже должны были пойти на расстрел. Мать, понятно, не хотела оставить детей (морозы были ужасные) и пошли вместе с детьми на расстрел.

Женщины рожали по дороге. Лично имел место такой случай: на привале в нескольких километрах отсюда женщина прибежала, что её дочь рожает. Действительно, кода я подошел к этой женщине (помню фамилия Глазер) ножки ребенка уже показались и мне пришлось вытянуть только головку. Через 10 минут нужно было двинуть дальше, но место не отошло, и женщина, не поднятая, лежала на снегу. Подходит румынский жандарм, говорю ему, что место не отошло и что через пять минут пойдем. На это жандарм одной пулей в голову убивает молодую женщину и прикладом убивает ребенка и когда мать бросается на труп своей дочери, убивает и ее. Знаю, что жила она в Одессе на Пересыпи и что муж ее был мобилизован в Красную Армию как старший лейтенант. Нас погнали дальше. Я оглядываюсь и вижу, как мальчишки как саранча бросились на эти еше не остывших два трупа, чтобы содрать с них последнюю рубашку.

Когда пригнали нас в Мостовое, загнали в здание бывшего райисполкома. Дом был не отоплен, без окон, дверей и стекол. Тут же встретила местная

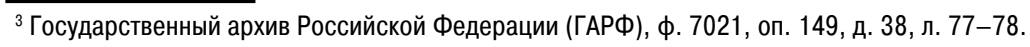


полиция. «Предлагали» они каждому «продать» пальто, костюм и т.д., убеждая каждого из нас, что эти пальто или костюм уже не нужны, ибо завтра или послезавтра ведут нас на костер, и действительно жутко было смотреть на недалеко от нашего «помещения» пылающий костер, а главное на запах человеческого горящего тела. Никогда этого не видел и не испытал, но этот запах меня еще преследует.

Каждый день утром приходили румыны-жандармы взять партию и повести на расстрел. Люди отдавали последнее с себя, чтобы выкупиться пойти на следующий день. Стягивали с себя сапоги, белье, пальто, чтобы только пойти на следующий день. Когда пришли за евреями, то мы все прятались по конюшням, в МТС, в снегу, но за нами гнались полицаи местные, не могу сказать, кто из них, ибо я их не видел и ни они меня, ибо если бы только заметили, то я бы уже не смог писать это показание... Знаю из людей, которые вырвались из ямы, что до самой ямы (3 км отсюда - хутор Веселое) сопровождала евреев полиция, а уже у самой ямы встретили евреев немцы в военной немецкой форме с знаками фашистской организации. Были среди этих немцев и наши колонисты-немцы, которые хотели выслужиться у новой фашистской власти и превосходили еще своими зверствами своих братьев по крови.

Как там происходили убийства, тоже знаю со слов знакомого еврея, который чуть недавно скрылся, перед приходом немцев и еще не встретился с ним. Вот что он мне сказал: привели их в Веселое (деревня недалеко отсюда) и загнали всех в один сарай. Там всех донага раздели - снимая как с мужчин, так и с женщин даже самую порванную рубашку - забирая все и выводя каждый раз по 6 человек на расстрел. Каждый взрослый человек получает пулю в голову - детей же добивают прикладом, по-видимому, чтобы сэкономить пулю. Их же сейчас бросали на пылающий костер. Люди, когда выходили из этого сарая, от испуга, не дожидаясь своей пули, бросались прямо в костер. Так погиб профессор Петрушкин из Одесского университета, который перед смертью просил меня передать его сыну - капитану Красной Армии, чтобы он мстил за смерть своего отца. Погиб же тогда профессор Одесского университета невропатолог Бланк и много врачей. Это было 19 марта 1942 г., я же был спрятан у одного врача, который с риском для своей жизни спас меня.

Что же касается граждан местного населения, то большая часть отнеслась очень сочувственно к евреям. Многие же, в особенности полиция, отбирали все у евреев и даже расстреливали. Так, например, Кипняк Коля имеет на своей совести по крайней мере несколько сот жертв. Он всегда являлся «охотником» и там, где даже румынские жандармы отказывались расстреливать детей - он это сделал. Более подробно я уже вчера изложил в прокуратуру военную. Были замешаны полицаи - Демешин, Ивангородский и еще некоторые, но я их хорошо не знаю, я их сам очень боялся и избегал их.
Расстреливала евреев также одна бывшая комсомолка Кузьмицкая, которая расстреливала первую еврейку, попавшуюся на глаза, если ей понравилось ее пальто, кофточка и туфли. Знаю, что уехала в Бессарабию. Грабил и выдавал евреев и русских партийных Маринеско - один содержатель ресторана, бывший механик в МТС. Когда евреи прятались, то многие из населения их скрывали, а другие указывали. Так, например, к последним принадлежит одна Маруся - фамилии не знаю. Работает в бане. Об этом мне тоже рассказывали евреи [...].

\section{Документ 2. Из показаний 25.4.1950 г. активного участника}

\section{расстрелов одесских евреев Рафаила Гекка (Heck)}

Однажды утром в конце февраля месяца 1942 года, точно я сейчас дату не помню, к нам в помещение отряда «Сельбшуц» приехали из районного центра - села Раштадт немецкий комендант Штетлер ${ }^{6}$, старший полицейский районной полиции «Сельбшуц» Керднер Петр и два немца из личной охраны Штетлера - Кресс и Кари Валентин. Штетлер был вооружен пистолетом, а Кертнер, Кресс и Кари имели при себе автоматы. Немецкий комендант Штетлер приказал нашему начальнику отряда «Сельбшуц» Фрелих Адаму Антоновичу срочно вызвать из квартир 12 человек полицейских, что и было немедленно исполнено. В числе вызванных полицейских был и я Гекк. Одновременно с вызовом полицейских комендант Штетлер дал приказание приготовить три подводы. Когда все вызванные полицейские собрались в помещении отряда «Сельбшуц», Фрелих Адам выдал каждому из нас по винтовке и по 25 штук патронов, которые я также получил. После раздачи оружия немецкий комендант Штетлер приказал всем собравшимся полицейским сесть на приготовленные подводы и следовать за ним.

В селе Новая Америка Штетлер нам ничего не сказал, на какую карательную операцию мы едем вместе с ним, но когда часов в 11 дня мы на подводах прибыли в деревню Сухая Балка, то Штетлер построил всех полицейских на улице и объявил, что сегодня под его руководством мы будем расстреливать евреев, которые привезены румынами из гор. Одесса и размещены временно в сараях в деревнях Сухая Балка, Степановка и Ильинка. Евреи содержались в тесноте в сараях, у которых крыши были полураскрыты, полы покрыты снегом и льдом. Измученные люди страдали от холода и истощения. Часть евреев находилась в пустых квартирах в деревне Подолянка. Все эти деревни до 1941 года имели один общий колхоз и входили в состав Веселиновского

${ }^{4}$ Архив управления Службы безопасности Украины в Николаевской области (далее - АуСБуно), ф. 11811, д. 842, л. 24-30 (дело по обвинению Гекк Рафаила Бенедиктовича).

${ }^{5}$ Правильно: «Зельбстшутц»/Selbstschutz - «самооборона».

${ }_{6}^{6}$ Унтерштурмфюрер СС Йоганн Штеттлер (Johann Stettler) в 194-1942 гг. был заместителем фюрера участковой команды XI (Bereichskommando XI) в Раштадте (ныне село Поречье Веселиновского района Николаевской области). 
района Одесской области. Расстояние между деревнями было небольшое полтора-два километра.

Объявляя нам место и порядок расстрела, комендант Штетлер сказал, что евреи будут расстреливаться в 800 метрах от деревни Подолянка возле большого сухого каменного колодца глубиной примерно 12 метров. Расстреливать будут он, Штетлер, старший полицейский Керднер и немцы из личной охраны Штетлера - Кресс и Кари Валентин. Полицейские из отряда «Сельбшуц» села Новая Америка Фрелих Адам, Браун Людвиг и Ренер Яков по приказанию Штетлера должны помогать расстреливать евреев из имевшихся винтовок. Остальные полицейские из отряда «Сельбшуц» села Новая Америка как-то: Штикер Евгений, Келлер Адам, Лейднер Иван, Вильд Никодим, Гарехт Роман и Сайферт Антон должны группами приводить евреев из деревень к месту расстрела, подгонять евреев прикладами к колодцу, в котором горела специально припасенная солома и после расстрела сталкивать их в горящий колодец. На меня, Антона Христиана, Марца Федора и Браунагель Ивана немецкий комендант Штетлер возложил обязанность охранять место злодеяния, где происходил расстрел евреев и сбрасывание их трупов в горящий колодец. Мы с оружием в руках должны были следить за тем, чтобы никто из обреченных на казнь евреев не убежал, а также наблюдать за тем, чтобы никто из местных жителей не проник за запретную зону и не стал бы невольным очевидцем совершенного нами злодеяния над евреями.

Всего по этому зверскому плану, составленному немецким комендантом Штетлер, возле деревни Подолянка в течение 3-4 часов нами было расстреляно и затем сброшено в горящий колодец человек 300 евреев. За точность названного количества казненных евреев я не ручаюсь, так как после совершения нами злодеяния среди полицейских села Новая Америка ходили слухи о том, что нами было расстреляно 280 человек и даже называли 400 человек.

Среди расстрелянных евреев было много матерей с грудными детьми. Матерей расстреливали из автоматов Керднер Петр, Кресс и Кари Валентин. Они же расстреливали и других. Грудных младенцев на руках у обезумевших матерей расстреливал из пистолета сам Штетлер. Среди зверски уничтоженных евреев были подростки, парни, молодые девушки, женщины и мужчины разных возрастов, а также дряхлые старухи и старики. Были среди них и целые еврейские семьи. Перед расстрелом лучшая одежда насильно снималась с жертв и складывалась на месте злодеяния. Таким образом, многие расстреливались в нижнем белье.

Штетлер перед расстрелом ограбил евреев, причем сделал он это обманным путем. Штетлер объявил евреям, что если они отдадут ему золотые кольца, браслеты, медальоны, золотые вещи, деньги и другие принадлежащие им ценности, в том числе и часы, то он им сохранит жизнь и расстреливать не будет. Евреи поверили этому обману и сдали Штетлеру все свои ценности, которые он после увез с собой в немецкую комендатуру. Отобрав ценности у евреев, Штетлер тут же дал команду расстрелять их, что и было исполнено.

Место расстрела представляло из себя страшную картину. Душераздирающие крики и вопли умирающих евреев были слышны далеко за пределами места злодеяния. Многие евреи, чтобы ускорить конец своим страданиям, подходили к горящему колодцу и, не дожидаясь выстрела, сами бросались в указанный колодец. В том случае, когда окровавленные евреи падали после выстрелов возле колодца, Штетлер заставлял самих евреев сбрасывать трупы и раненых в горящий колодец. Когда расстрелы были закончены и трупы замученных жертв сброшены в горящий колодец, немецкий комендант Штетлер приказал старосте села Сухая Балка, фамилию его я забыл, засыпать колодец землей, что и было сделано в нашем присутствии. Потом тот же Штетлер построил всех участников расстрела евреев и строго объявил, чтобы мы никому ничего не рассказывали об уничтожении нами евреев и держали это в тайне. Затем мы сели на свои подводы и разъехались по домам.

Как я заметил, немецкий комендант Штетлер отнятую им одежду у евреев отдал старосте деревни Сухая Балка. Куда девал одежду староста, мне не известно. После моего отъезда с места расстрела евреев Штетлер вместе со старшим полицейским Керднер Петром, Кресс и Кари Валентином оставался еще на месте злодеяния...

Второй раз я участвовал в массовом расстреле евреев вблизи села Ястребиново Вознесенского района Одесской области. Было это в середине марта месяца 1942 года, точно я сейчас дату не помню.

По приказу немецкого коменданта Штетлера на расстрел евреев было мобилизовано свыше 100 полицейских, прибывших с винтовками на 30 подводах из сел Новая Америка, Раштат и Мюнхен. В числе приехавших полицейских был и я - Гекк. Всего было расстреляно в этот раз примерно до 500 человек евреев, в том числе старики и дети. Так как все полицейские для удобства расстрела евреев были разбиты на группы по 8-10 человек, то я Гекк вместе с 9 другими полицейскими стрелял из винтовки по группе евреев, в которой насчитывалось 50-60 человек. Обреченные на казнь евреи, как и в первом случае массового уничтожения евреев, в котором я участвовал, содержались в каменных сараях в деревне Ястребиново, где крыши были раскрыты и люди валялись на полу, покрытом льдом и снегом, умирая от холода и голода. Специально выделенная группа полицейских в количестве 25 человек насильно гнали евреев из сараев к месту расстрела, где они подводились к цементированным колодцам глубиной от 25 до 30 метров, расстреливались по команде коменданта Штетлера и сталкивались в колодцы. Душераздирающие крики и вопли евреев разносились по местности.

Перед тем как расстрелять евреев, Штетлер отнял у жертв золотые вещи, ценности и деньги, а также другое имушество. Мешки же, в которых находились вещи евреев, отдал помощнику старосты Фрейлиху Матвею 
Антоновичу. Что же касается отнятых ценностей, то Штетлер увез их с собой в комендатуру.

Расстрел и подготовка к нему длились часов шесть.

По окончании расстрела евреев Штетлер и его приближенные остались на месте для сжигания трупов в колодцах, я же вместе с полицейскими из села Новая Америка выехал домой.

Снятую одежду с евреев после привезли в помещение немецкой комендатуры, продезинфицировали и раздали немцам, проживающим в селах Новая Америка, Раштат и Мюнхен. Из награбленных вещей я лично получил от старосты села для своей семьи детское пальто лет на 14 , шерстяной женский платок и мужские кожаные полуботинки. Помимо этого, на месте совершенного злодеяния над евреями немецкий комендант Штетлер мне и каждому участнику расстрела евреев выдал по 3 немецких марки.

\section{Документ 3. Показаниях бывшего члена отряда самообороны} хутора Новая Америка Петера Хекка о расстреле одесских евреев, содержавшихся в селе Подолянка'

[...] В начале 1942 г., зимой, в январе или феврале, точно вспомнить я не могу, мы и другие полицейские отряда самообороны Новой Америки по приказу Адама Фрелиха на двух или трех санях или повозках - точно я вспомнить не могу - поехали из Новой Америки в Подолянку, чтобы расстрелять советских граждан, которые находились в конюшне села Подолянка. Мы поехали через село Сухая Балка. У меня и других полицейских были винтовки русского образца, которые нам перед отъездом из Новой Америки выдал Адам Фрелих. Вместе с винтовкой Адам Фрелих выдал мне и патроны для винтовки. Сколько патронов я получил, я уже не знаю.

Когда мы прибыли в Подолянку, мы все остались близ конюшни. Затем по приказу Адама Фрелиха мы выгнали людей из конюшни и велели им построиться в колонну. Среди этих людей были женщины, дети и старики. Почти все они были евреями. Кто кроме меня выгонял людей из конюшни, я вспомнить не могу. Затем все приговоренные к смерти люди были отведены к заброшенному колодцу за селом Подолянка. Я не вел людей, а ехал на санях или повозке слева от колонны [...] Когда я ехал рядом с колонной, я наблюдал за людьми в колонне. Их было около 200, точное количество я указать не могу, в основном женщины, многие из которых несли на руках маленьких детей. Они не знали, куда они были доставлены, поэтому они шли молча, с поникшей головой. Женщины были закутаны в платки, так как была зима, и было очень холодно. Люди должны были остановиться в 50 метрах от колодца. Адам Фрелих по приказу коменданта Штеттлера заявил им, что кто сдаст ценности и деньги, тому будет сохранена жизнь. Надеясь

${ }^{7}$ Bundesarchiv (BArch) B162/2314, BI. 316-319. спасти свою жизнь, люди начали отдавать ценности и деньги. У тех, кто это не сделал, они были отобраны. Ценности и деньги у людей отбирали Адам Фрелих и я. Ценности и золото были сложены на расстеленное одеяло. Когда ценности были отобраны, людей заставили раздеваться до нижнего белья и группами отводили на край колодца. Полицейские, которых было столько, сколько приводили людей к колодцу, убивали их выстрелами в затылок. Сначала были расстреляны люди, которые не сдали никаких ценностей. Я и Фрелих подошли к людям, которые сдали золото и ценные вещи и пообещали им, что они останутся в живых, если отдадут еще золото и ценные вещи. После этого некоторые из них отдали еще несколько ценных вещей. Когда все золото и все ценные вещи был сданы, также теми, кто второй раз отдал ценные вещи, эти люди также должны были раздеться до нижнего белья и после привода к колодцу были расстреляны. Я лично застрелил из винтовки 4 женщин и одну женщину ранил в плечо - в правое или левое, я уже не знаю.

Во время всего расстрела я находился среди полицейских и убивал указанных людей. Кто из полицейских стоял рядом со мной и расстреливал людей, я не знаю; я на это не обращал внимание. Я стоял в ряду полицейских справа, спиной к селу Подолянка и лицом к колодцу. Вид убитых женщин я не могу описать, так как люди подводились так, что они стояли спиной ко мне.

Картина расстрела была ужасной. Люди, у которых не было маленьких детей, до самого расстрела молчали и не поднимали головы. Глаза женщин, у которых были маленькие дети, были безумными и страшными. Когда женщины с детьми были приведены к колодцу на расстрел, Петер Гертнер из своего пистолета сначала убивал детей - так, чтобы не женщины, а только дети были поражены. Он расстреливал детей, когда они были на руках у матерей. Матери, которые держали на руках трупы своих детей, кричали от ужаса и сходили с ума. Затем полицейские выстрелами в затылок расстреливали матерей.

\section{Документ 4. Из показаний бывшего полицейского в селе} Новопетровка (Веселиновский район) Яковенко на предварительном следствии в 1944 г. ${ }^{8}$

В марте 1942 г. в селах Н-Петровка и Первенец происходил массовый расстрел советских граждан, где я был организатором этого расстрела. За три дня до расстрела из немецкой колонии Вормс в село Ново-Петровку приехал немецкий комендант... Он подошел ко мне и заявил, чтобы я создал условия, необходимые для расстрела советских граждан. Я в свою очередь коменданту заявил, что все подготовлено, после этого комендант уехал, а я вызвал

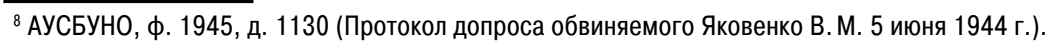


к себе полицейского с х. Первенец Устинского Владимира, но ему уже ктото приказал подготовить яму, и тут же я вызвал к себе бригадира Бондаренко Савелия, которому объяснил, что надо вырыть яму для расстрела советских граждан и указал ему место. Бондаренко взял колхозников и послал в указанное мною место копать яму. На третий день комендант обратно приехал к нам в село вместе с немцами около 20 человек... Я подошел к коменданту, который мне заявил, что сейчас будет производить расстрел граждан, содержавшихся в конюшне. Я безусловно ему ответил, что возражать против такого мероприятия не намерен, только нужно расстреливать на краю хутора. На это комендант дал свое согласие. Я ему указал подходящее место, где бы можно было расстреливать советских граждан. После того как вопросы о месте расстрела были мною разрешены, немцы из сарая вывели примерно 50 человек, отвели метров 100 в сторону и объявили, у кого есть марки и золото отойдите в сторону. Некоторые советские граждане отошли в сторону, а тех лиц, которым нечем было откупиться, ставили в колонку по 5-7 человек, стреляли разрывной пулей в затылок, сразу несколько граждан падало, а кто не был застрелен, в того стреляли вторично. Таким образом повторяли несколько раз. Закончился расстрел граждан, не имеющих золото, стали раздевать и тех граждан, которые откупились, и также ставили в колонку и расстреливали. В первый день расстрела было зверски уничтожено мужчин 100 человек, женщин 40 человек и детей от грудного и до 10-летнего возраста 10 человек.

Детей не расстреливали, а их убивал дрючком немецкий полицейский по имени Николай. В этом расстреле советских граждан принимали участие немцы около 20 человек, я и полицейский хутора Первенец Устинский Володя.

После расстрела советских граждан, чтобы скрыть свои следы преступления, я организовал вывоз из села трупов в заранее приготовленную яму.

После того как немцы-палачи из села выехали, я обеспечил охрану оставшихся еще в живых советских граждан, обреченных на смерть. Я выделил патрулей для охраны граждан - Бондаренко Михаила и Ляшенко Федора Кирилловича, дал им инструктаж, чтобы они никого из советских граждан, обреченных на смерть, из сарая не выпускали, и всех задержанных подозрительных советских граждан в селе приводили в сарай. На этом мой трудовой день кончился.

На второй день к нам в село обратно приехал этот же состав 20 немцев и комендант. Приехали они к сараю, где содержались советские граждане, к ним подошел я и заявил, что яма готова, и указал ее место нахождения.

Тут же немцы всех советских граждан выгнали из сарая и конвоем повели к яме. Я шел вместе с немцами, указывал коменданту место нахождения ямы. Когда привели всех к яме, то повторяли тот же процесс, что и в первый день расстрела, то есть отобрали золото, раздевали донага и в затылок по несколько человек расстреливали. Всего на второй день было расстреляно около 350 человек, из них мужчин 100 человек, старух и девушек 230 человек и детей от грудного до 10-летнего возраста около 20 человек. Детей также убивал немец Николай дрючком. В этом расстреле принимали участие немцы, полицейский Устинский и я.

После расстрела советских граждан я постарался скрыть следы своей черной работы. Я приказал бригадиру Бондаренко привезти конопли, что и было сделано. Подвезли два воза конопли, обложили трупы коноплей и подожгли. 